\title{
Entry Dynamics of Startup Companies and the Drivers of Their Growth in the Nascent Blockchain Industry
}

\author{
VIKTORIIA SEMENOVA* \\ *Corvinus University of Budapest, Institute for the Development of Enterprises; \\ viktoriia.semenova@stud.uni-corvinus.hu
}

DOI: $10.14267 / 978-963-503-867-1 \_13$

\begin{abstract}
The purpose of the paper is to discuss the characteristics of the blockchain (hereinafter "BT") industry and factors that affect the success of BT-based startup companies. Due to the novelty of BT technology, the current period of its development is associated with a high number of newly emerging firms that are predominant in the BT industry. The study seeks to address the two main research questions: What are the key characteristics of the BT industry? What are the factors that determine the success of BT-based companies? To answer these questions, the method of the systematic literature review was applied. The discussion of the reviewed 43 publications led to the classification of literature sources into six categories, including research streams on BT in the contexts of entrepreneurial finance, institutional theory, digital and social entrepreneurship, business models, and international business. The results suggested that the early success of the BT-based startups' entry and growth related to the supportive entrepreneurial environments, a greater degree of regulatory clarity, the formation of strategic associations, entrepreneur's active engagement in sharing expertise and shaping the regulations and standards, a profound business model, and experienced management. It is recommended that policymakers should support the creation of new ventures and the transfer of knowledge about BT. Managers of established companies should cooperate with startups to adopt BT applications into their business models. Future research should be based on empirical research studies, namely cluster analysis, to identify the determinants of success/failure of BT-enabled startup firms. This paper contributes to BT research and the literature on the emergence of new industrial fields and ventures.
\end{abstract}

Keywords: blockchain industry, venture, start-up

Funding: The present publication is the outcome of the project "From Talent to Young Researcher project aimed at activities supporting the research career model in higher education," identifier EFOP3.6.3-VEKOP-16-2017-00007 co-supported by the European Union, Hungary, and the European Social Fund. The author would like to thank the National Bank of Hungary for the financial support under the Research Excellence Award. 


\section{Introduction}

The period of technology emergence is commonly associated with newly created firms. According to technology life-cycle theories, the preferred mode of technology exploitation is new firms, provided that technology is novel, and a market tends toward segmentation (Shane, 2001). Audretsch (2002) suggests that small firms serve as agents of change and creators of innovations by ensuring an essential source of new ideas and experimentation and being able to adopt new technologies faster than larger enterprises. The development of blockchain (hereinafter referred to as: BT) technologies has resulted in the creation of a variety of companies, products, and services as well as the formation of a BT ecosystem that is a dynamic space with many new entries and exits. The technology of BT has become an industry in its own right (Liu, 2020). The technology has triggered innovation processes by creating new capabilities for entrepreneurs and reshaping the nature of innovation and entrepreneurship (Chen, 2018; Massey et al., 2017).

The purpose of this study is to analyse the BT-related ventures and factors facilitating the creation and growth of such firms in the nascent BT industry. This study seeks to address two main research questions: (1) What are the key characteristics of the BT industry? (2) What are the factors that determine the success of BT-based companies? To answer these questions, a systematic literature review was conducted. The discussion of the reviewed 43 papers led to their classification into six categories and enabled answering to the formulated questions. This paper contributes to the literature on the emergence of new industries (Colombelli et al., 2014; Giarratana, 2004; Krafft et al., 2014), the study of new venture formation (Shane, 2001), and the BT research that is still in its infancy (Kher et al., 2020).

The remainder of the paper is organised as follows. In the theoretical part, the formation of new industries and guidelines for analysing new venture creation are discussed. Thirdly, it is followed by a method section describing how this conceptual research was carried out. In the result part, the findings of this research were analysed based on previous research works and presented in a tabular form. Finally, discussion and concluding remarks, followed by theoretical and managerial implications and future research directions are outlined. 


\section{Theoretical background on the birth of new industries and ventures}

The process of new industries formation is shaped by the dynamics of knowledge creation in the geographic and technological space as well as institutional setting. There are a number of forces that drive the formation of industry, including the creation of new innovative firms, mobility of labour force enabling knowledge transfer and exploitation in novel contexts, establishment and evolution of network linkages (Krafft et al., 2014). The competencies which are already developed by local agents ensure the successful emergence of new activities. Colombelli et al. (2014) affirmed that the dynamic was more evident when such activities were based on brand new technologies.

In order to analyse new firms' creation in the process of shaping industries, Gartner (1985) and Giarratana (2004) proposed some guidelines. According to them, three main areas are required to assess: the environment, the new product or process, and the entrepreneurs as well as their connection with each other. First, the organisational forms of start-ups make them critical in opening new markets as they are better adapted to young turbulent environments (Giarratana, 2004). However, Jáki et al. (2019) state that all start-ups need a supportive ecosystem for rapid development and easy access to global markets. Entrepreneur-friendly ecosystems also have a huge positive influence on firm entry and growth (Gartner, 1985). So, the specific features of the environments should be considered while analysing the conditions underpinning the emergence of new industries and firms. Moreover, the formation of new industry shows cross-country differences due to various initial institutional and technological regimes (Casper \& Whitley, 2004).

Secondly, the rising demand in the digital sphere causes an increase in the complexity and the spectrum of different products. This process provides an opportunity for smaller companies and start-ups to exploit these specific needs and challenge market leaders in well-defined niche areas by creating new products and processes. Thirdly, in the earlier periods of the firm existence, its survival primarily depends on the founder's abilities and competencies. In exploiting the same business opportunities, entrepreneurs follow different approaches. This results in a high degree of heterogeneity among the firms (Gartner, 1985; Giarratana, 2004) whose most important drivers of growth are specialisation in a particular niche, the introduction of a distinguished innovative product, and international expansion. Thus, this paper is devoted to studying the technology of BT and the concomitant BT industry as well as the characteristics of BT-enabled startup firms. 


\section{Methodology}

The systematic review methodology was adopted and articles were searched in the Web of Science (WoS) citation database to address the research objective and questions. Firstly, the method of the systematic literature review was chosen because it could generate valuable information and identify practical implementation and conceptual frameworks from available resources (Hart, 1998). Secondly, I limited the search of the papers to one database as the WoS was considered a significant scientific instrument across countries and knowledge domains (Li et al., 2018). Besides, the WoS and Scopus databases provide fairly similar results (Harzing \& Alakangas, 2016).

As of January 2021, a combination of the following search strings - "blockchain" AND "entrepreneurship", "blockchain" AND "new venture", "blockchain" AND "startup" - resulted in 47, 27, and 52 papers, respectively. After screening title, keywords, abstract, and content, several papers with the following parameters were excluded: papers without fulltext availability, papers that were duplicates, editorial insights, papers with technical description and not relevant to the research topic (e.g., Fintech), papers that had some other meaning than BT used in computer science (e.g., smart contracts, Bitcoin). In a few papers, the term 'blockchain' was mentioned in the title but the technology was not described or somehow presented in the works.

I used the SCImago journal ranking (SJR) to include high-quality, peer-reviewed journals, though the conference papers and articles from lower-ranking journals were also added to ensure the relevance and completeness of the review. The final sample comprises 43 publications on the most researched aspects of BT, though I do not state that the set of selected papers is exhaustive. Most of the reviewed articles were primarily published in such high-impact Q1 journals as Business Horizons (3 articles), Small Business Economics (3 articles), Journal of Business Research (2 papers), Research Policy (2 papers), Journal of Business Venturing, Foundations and Trends in Entrepreneurship, Technological Forecasting and Social Change, and others. 3 proceedings papers and 3 articles from journals not presented in the SCImago rank were also included in the sample. 


\section{Results}

This section discusses the results of the literature review. An examination of the available papers demonstrates the nascent stage of academic interest in the field of new technology (i.e. BT). The topic has recently received attention because the majority of papers are from the last three years (2018 with 8 papers; 2019 - 12 papers; 2020 - 21 papers) and 1 paper from 2017 and 2016. This indicates the novelty of the topic and the reason why a comprehensive analysis on BT-based firms has not been elaborated yet. This finding is consistent with Chalmers et al. (2019) notice about a small number of studies exploring entrepreneurship and BT. Meanwhile, the analysis of existing articles has shown that the papers can be divided into the following six categories (see Table 1):

(1) BT and Entrepreneurial finance - 22 papers.

This category contains papers that were mainly conducted in the context of entrepreneurial finance. Ahluwalia et al. (2020) conducted the first research on explaining startup finance and BT technologies in the framework of transaction costs economics. In the field of entrepreneurial finance, the information asymmetries between an investor and an entrepreneur and transaction costs associated with the financing of startup companies are high. In this regard, BT is claimed to mitigate those issues by reducing costs and present with alternatives to such activities. The ability of BT to tokenise and decentralise money and a broad range of scarce assets beyond currencies led to the emergence of a new way of fundraising - initial coin offerings (ICOs) - that allows raising funds directly from investors across the globe (Chen, 2018; Jackson, 2017). The majority of entrepreneurship research examines ICOs as a novel form of entrepreneurial finance for highly innovative BT ventures (Chen, 2019; Kher et al., 2020). Schückes and Gutmann (2020) enriched the literature on entrepreneurial finance by advancing the understanding of ICOs and the literature on entrepreneurial decision making by explaining the entrepreneurs' funding choice.

(2) BT as an external enabler/Digital entrepreneurship - 6 papers.

Insofar as a growing body of entrepreneurship literature has focused on the role of digital technologies in entrepreneurial processes and practices (Nambisan, 2017), this category covers papers on BT as a digital enabler and entrepreneurial activities for developing novel innovation systems. Mickiewicz and Rebmann (2020) indicated that BT enabled entrepreneurs to create a new form of distributed trust between strangers. Unalan and Ozcan (2020) stated about the increased distribution of networks and collaboration and democratisation of entrepreneurship by the new funding landscape. The study of Chalmers et al. (2019) on entrepreneurial firms using BT for developing new venture ideas in the 
music industry provided a novel view on intersections between external enabler theory and digital entrepreneurship.

(3) BT and Institutional theory/economics/cryptoeconomics - 5 papers.

In this category, papers mostly examine the institutional context of the entrepreneurial discovery of BT applications. Allen et al. (2020) state that BT infrastructure provides new avenues for entrepreneurship and innovation amongst previously unforeseen domains of economic activities across firms, industries, and states. The technology has driven a new process of institutional discovery that challenges government hegemonies. BT has also expanded the scope for entrepreneurial activities in monetary institutions (Berg et al., 2020). According to Allen (2019), BT policy enables entrepreneurs to test and trial their ideas in markets, so there is a need for economic and political reform of various regulatory barriers that inhibit entrepreneurial actions.

(4) BT and Social entrepreneurship - 3 papers.

A few publications are linked to the topic of social entrepreneurship. Jain and Simha (2018) explained how BT could be adapted for the field of charitable donations and social entrepreneurship by introducing a distributed ledger application for the world of citizen philanthropy and social entrepreneurship. Gogan et al. (2020) enriched a small stream of studies on IT-enabled hybrid social enterprises and explored how a social entrepreneur saw an opportunity and built a BT-based platform.

(5) BT and Business models -6 papers.

In this category, the findings of the presented papers show how BT can create business value and contribute to the technology-driven blockchain literature. Morkunas et al. (2019) and Weking et al. (2019) noted the scarcity of research in relation to the impact of blockchain on business models, creation, and delivery of value. Park and Sung (2020) pointed to a lack of studies on analysing the business feasibility for value creation and revenue generation from the eyes of a technology entrepreneur. Meanwhile, research on business model promotes an understanding of the impact of BT on existing and new business models. According to Kher et al. (2020), broader research on new business models of startup firms and technology adoption is critical for the development of this field.

(6) BT and Internationalisation of firm - 1 paper.

Zalan (2018) described a new phenomenon in international business, that is an increasing number of technology-based born global start-ups with distinctive characteristics, on the 
example of BT-enabled ventures which are originally "born global" due to characteristics of the technology.

Table 1: Classification and summary of the reviewed papers*

\begin{tabular}{|c|c|c|}
\hline Author(s) / Topic & Research type & Findings \\
\hline \multicolumn{3}{|l|}{ BT \& Entrepreneurial finance } \\
\hline $\begin{array}{l}\text { Ahluwalia, Mahto, \& Guerrero } \\
\text { (2020) } \\
\text { Blockchain technology and } \\
\text { startup financing: A transaction } \\
\text { cost economics perspective }\end{array}$ & $\begin{array}{c}\text { Conceptual } \\
\text { paper }\end{array}$ & $\begin{array}{l}\text { BT can significantly reduce the transaction costs for } \\
\text { stakeholders in the entrepreneurial ecosystem, such as } \\
\text { entrepreneurs, angels, and VCs. }\end{array}$ \\
\hline Chen (2018) & Conceptual & BT tokens may democratise \\
\hline $\begin{array}{l}\text { Blockchain tokens and the } \\
\text { potential democratisation of } \\
\text { entrepreneurship and innovation }\end{array}$ & paper & $\begin{array}{l}\text { - entrepreneurship by giving entrepreneurs new ways to } \\
\text { raise funds and engage stakeholders, } \\
\text { - innovation by giving innovators a new way to develop, } \\
\text { deploy, and diffuse decentralised applications. }\end{array}$ \\
\hline $\begin{array}{l}\text { Park, Shin, \& Choy (2020) } \\
\text { Early mover (dis)advantages } \\
\text { and knowledge spillover effects } \\
\text { on blockchain startups' funding } \\
\text { and innovation performance }\end{array}$ & $\begin{array}{l}\text { Empirical } \\
\text { research study } \\
\text { / Quantitative }\end{array}$ & $\begin{array}{l}\text { Early entry allows founders of BT startups to gain early } \\
\text { mover advantages, especially regarding funding } \\
\text { attraction from venture capitals. Disadvantages posed } \\
\text { for late comer start-ups may be alleviated by pursuing } \\
\text { external activities such as conference participation and } \\
\text { presentation. }\end{array}$ \\
\hline $\begin{array}{l}\text { Schückes \& Gutmann (2020) } \\
\text { Why do startups pursue ICOs? } \\
\text { The role of economic drivers and } \\
\text { social identity on funding choice }\end{array}$ & $\begin{array}{l}\text { Empirical } \\
\text { research study } \\
\text { / Qualitative }\end{array}$ & $\begin{array}{l}\text { The entrepreneur's social identity in conjunction with } \\
\text { the enabling mechanisms of BT shape entrepreneurial } \\
\text { pursuits and funding choice. }\end{array}$ \\
\hline \multicolumn{3}{|c|}{ BT as an external enabler/Digital entrepreneurship } \\
\hline $\begin{array}{l}\text { Chalmers, Matthews, \& Hyslop } \\
\text { (2019) } \\
\text { Blockchain as an external } \\
\text { enabler of new venture ideas: } \\
\text { Digital entrepreneurs \& the } \\
\text { disintermediation of the global } \\
\text { music industry }\end{array}$ & $\begin{array}{c}\text { Literature } \\
\text { review, } 11 \text { case } \\
\text { studies / } \\
\text { A model of } \\
\text { new venture } \\
\text { idea \& } \\
\text { external } \\
\text { enabler } \\
\text { shaping }\end{array}$ & $\begin{array}{l}3 \text { external enablers of new venture ideas in the context } \\
\text { of music industry: ideology, market volatility, and the } \\
\text { focal technological enabler BT. Entrepreneurial actors } \\
\text { engaged in a set of venture-level work practices that } \\
\text { allowed them to: discover and learn about enablers; scan } \\
\text { the industry context to establish a differentiated value } \\
\text { proposition; synthesise and ideate a range of new venture } \\
\text { ideas. }\end{array}$ \\
\hline $\begin{array}{l}\text { Mickiewicz \& Rebmann (2020) } \\
\text { Entrepreneurship as Trust }\end{array}$ & $\begin{array}{l}\text { Conceptual } \\
\text { paper }\end{array}$ & $\begin{array}{l}\mathrm{BT} \text { is enabling entrepreneurs to create a new form of } \\
\text { distributed trust between strangers. }\end{array}$ \\
\hline
\end{tabular}


BT \& Institutional and entrepreneurial theory / institutional economics/cryptoeconomics

$\begin{array}{lcl}\begin{array}{l}\text { Allen, Berg, Markey-Towler, } \\ \text { Novak, \& Potts (2020) }\end{array} & \begin{array}{c}\text { Conceptual } \\ \text { paper }\end{array} & \begin{array}{l}\text { BTs are new digital platforms that lower the costs of } \\ \text { institutional innovation by offering a decentralised } \\ \text { economic infrastructure for the new economy. }\end{array} \\ \begin{array}{l}\text { Blockstitutional technologies: } \\ \text { Implications for innovation } \\ \text { policy }\end{array} & & \begin{array}{l}\text { BT infrastructure is providing new avenues for } \\ \text { entrepreneurship and innovation amongst previously } \\ \text { unforeseen domains of economic activities. }\end{array} \\ \begin{array}{l}\text { Berg, Markey-Towler, \& Novak } \\ \text { (2020) }\end{array} & \begin{array}{c}5 \text { case studies } \\ \text { based on }\end{array} & \begin{array}{l}\text { BT offers private enterprise a new mechanism to manage } \\ \text { and regulate opportunistic behaviour. }\end{array} \\ \begin{array}{l}\text { Blockchains: Less government, } \\ \text { more market }\end{array} & \text { secondary } & \text { BT has expanded the scope for entrepreneurial action in } \\ & \text { sources } & \begin{array}{l}\text { monetary institutions and driven a new process of } \\ \text { institutional discovery. }\end{array}\end{array}$

BT \& Social entrepreneurship

\begin{tabular}{lcl}
$\begin{array}{l}\text { Devereaux (2020) } \\
\text { The digital Wild West: on social } \\
\text { entrepreneurship in } \\
\text { extended reality }\end{array}$ & $\begin{array}{c}\text { Conceptual } \\
\text { paper }\end{array}$ & $\begin{array}{l}\text { Social entrepreneurship in BT solutions may very well be } \\
\text { able to meet some of the challenges presented by rapidly } \\
\text { advancing extended reality (XR). }\end{array}$ \\
$\begin{array}{l}\text { Gogan \& Goode } \\
\text { (2020) }\end{array}$ & $\begin{array}{c}\text { A single-case } \\
\text { study }\end{array}$ & $\begin{array}{l}\text { Multiple forms of IT agility, multiple forms of business } \\
\text { agility, and a unique form of social-commercial agility } \\
\text { help an IT-enabled hybrid social startup persist, despite } \\
\text { startup }\end{array}$ \\
& $\begin{array}{l}\text { financial and other challenges. BT is an early stage IS } \\
\text { innovation in health care. }\end{array}$ \\
\hline
\end{tabular}

BT \& Business models

$\begin{array}{lcl}\begin{array}{l}\text { Morkunas, Paschen, \& Boon } \\ (2019)\end{array} & \begin{array}{c}\text { Case studies } \\ \text { based on } \\ \text { secondary } \\ \text { sources } \\ \begin{array}{l}\text { How blockchain technologies } \\ \text { impact your business model }\end{array}\end{array} & \begin{array}{l}\text { Presenting the influence BT technologies can have on a } \\ \text { firm's business model based on the examples of BT } \\ \text { development startups across different industries and } \\ \text { countries. }\end{array} \\ \begin{array}{l}\text { Weking, Mandalenakis, Hein, } \\ \text { Hermes, Böhm, \& Krcmar }\end{array} & \begin{array}{c}\text { Design science } \\ \text { research }\end{array} & \begin{array}{l}\text { Based on 99 BT ventures, 5 archetypal patterns of } \\ \text { business models leveraging BT are defined: }\end{array} \\ \begin{array}{l}\text { (2019) } \\ \text { The impact of blockchain } \\ \text { technology on business models }-\end{array} & \begin{array}{l}\text { BT for Security, BT Technology as Offering, and BT for } \\ \text { a taxonomy and archetypal } \\ \text { patterns }\end{array} & \text { Monetary Value Transfer. }\end{array}$


BT \& Internationalisation of firm

Zalan (2018)

Born global on blockchain
General review

/Viewpoint
Most of start-ups are genuinely "born global" as there are no technical restrictions on BT deployment because it is open sourced, decentralised, and globally distributed by its nature, and a start-up's developer teams, funders, users and exchanges listing their tokens can be located anywhere around the globe.

Source: own compilation. Note: Due to the space limitation, a few papers are presented in the table. The full version is available from the author upon request.

\section{Discussion and recommendations}

Based on the literature review of the research works, the key characteristics of the BT industry are primarily summarised. According to Park et al. (2020), the ecosystem of BT innovation differs from other existing high technology industries in terms of competition among players. Firstly, the sharing and disclosure of technological details are active in the BT industry through the development of platforms (e.g., Bitcoin, Ethereum) and white papers published by start-ups to disseminate their vision for a new offering (Fisch, 2019). In contrast, firms in other technology industries tend to conceal their technologies. Secondly, the development and imitation of BT are easier compared with other high technologies due to its features and underlying algorithms. The BT industry is characterised by active knowledge transfers among startups (e.g., conference activities, Demo Days). In general, BT innovation is widely exploited by highly innovative startups; this is in line with previous research works (Audretsch, 2002; Giarratana, 2004; Shane, 2001). Most of those start-ups are at the early R\&D stage and "born global" companies (Zalan, 2018). Further, the determining factors on the success of BT-based companies are outlined by applying Giarratana's (2004) guidelines:

Environment. The conditions of the external environment affect the adoption of BT and the entry and success of the BT-enabled firms. Countries that exhibit a more welcoming policy stance are more likely to attract entrepreneurs and investors in the cryptoeconomic blockchain space (Novak, 2019). Allen (2019) also suggests that the BT policy within early-stage entrepreneurship should focus on how existing policies inhibit the process of an emergent entrepreneurial organisation. One of the factors to the success or failure of the venture are business strategies and due diligence to comply with all relevant regulations (Dos Santos \& Chaczko, 2019). Therefore, the barriers to full use of BT can be mitigated via the formation of strategic associations and entrepreneurs' dissemination work that influence regulations and standards (Chalmers et al., 2019). 
Both startup and incumbent companies may rely on collaborative networks (García Sáez, 2020).

Entrepreneurs. In the early stages of firm creation, an entrepreneur acts on behalf of the entire organisation by interacting with broader community and industry context (Gogan et al., 2020). Entrepreneurs' active engagement in sharing their expertise in core business activities positively influences the status of the firm. Their dissemination and field-level shaping activities on new technology can impact the competitors' new venture ideation processes and establish credibility within the competitive space. Chalmers et al. (2019) stated that such work was instrumental in demystifying BT to established firms and accelerating the potential collaboration options. In order to attract talent, García Sáez (2020) recommended start-ups to communicate openly about their objectives, values, and culture.

New product/process. According to Fiedler and Sandner (2017), the BT startup ecosystem is dominated by start-ups with a profound business model and experienced management that was able to solve infrastructural problems or inefficiencies. The technology can both provide disruption in well-established business models and offer solutions to industries with structural issues (Nowiński \& Kozma, 2017). Due to the rapidly evolving nature of BT, Chalmers et al. (2019) stated the necessity for ventures to constantly update their knowledge of technological developments and their alignment with venture ideas.

Thus, the present research work contributed to the literature on BT-related research by presenting classification on the existing literature sources dedicated to BT and entrepreneurship. The research stream on BT and novel forms of entrepreneurial finance (i.e., ICOs) is predominant, followed by the research on BT in the contexts of institutional and entrepreneurial theory, digital and social entrepreneurship, business models, and international business. A summary of the characteristics of the BT industry and new BTbased ventures was presented.

Policymakers are recommended to support the creation of new ventures and provide incentives for entrepreneurs and other business-oriented people to set up new high-tech firms. As regards incumbent companies, managers should cooperate with start-ups to adopt BT applications into their business models and profit from this technology. Future research should be based on empirical research studies (both qualitative and quantitative), namely cluster analysis, to identify the determinants of success and failure of BT-enabled firms 


\section{References}

Ahluwalia, S., Mahto, R. V., \& Guerrero, M. (2020). Blockchain technology and startup financing: A transaction cost economics perspective. Technological Forecasting and Social Change, 151, 119854. https://doi.org/10.1016/j.techfore.2019.119854

Allen, D. W. E. (2019). Governing the entrepreneurial discovery of blockchain applications. Journal of Entrepreneurship and Public Policy, 9(2), 194-212. https://doi.org/10.1108/JEPP-03-2019-0017

Allen, D. W. E., Berg, C., Markey-Towler, B., Novak, M., \& Potts, J. (2020). Blockchain and the evolution of institutional technologies: Implications for innovation policy. Research Policy, 49(1), 103865. https://doi.org/10.1016/j.respol.2019.103865

Audretsch, D. B. (2002). The dynamic role of small firms: Evidence from the U.S. Small Business Economics, 18(1-3), 13-40. https://doi.org/10.1023/A:1015105222884

Berg, A., Markey-Towler, B., \& Novak, M. (2020). Blockchains: Less government, more market. Journal of Private Enterprise, 35(2), 1-21. https://doi.org/10.2139/ssrn.3301714

Casper, S., \& Whitley, R. (2004). Managing competences in entrepreneurial technology firms: A comparative institutional analysis of Germany, Sweden and the UK. Research Policy, 33(1), 89-106. https://doi.org/10.1016/S0048-7333(03)00100-8

Chalmers, D., Matthews, R., \& Hyslop, A. (2019). Blockchain as an external enabler of new venture ideas: Digital entrepreneurs and the disintermediation of the global music industry. Journal of Business Research, 1-15. https://doi.org/10.1016/j.jbusres.2019.09.002

Chen, K. (2019). Information asymmetry in initial coin offerings (ICOs): Investigating the effects of multiple channel signals. Electronic Commerce Research and Applications, 36, 100858. https://doi.org/10.1016/j.elerap.2019.100858

Chen, Y. (2018). Blockchain tokens and the potential democratisation of entrepreneurship and innovation. Business Horizons, 61(4), 567-575. https://doi.org/10.1016/j.bushor.2018.03.006

Colombelli, A., Krafft, J., \& Quatraro, F. (2014). The emergence of new technology-based sectors in European regions: A proximity-based analysis of nanotechnology. Research Policy, 43(10), 1681-1696. https://doi.org/10.1016/j.respol.2014.07.008

Devereaux, A. (2020). The digital Wild West: on social entrepreneurship in extended reality. Journal of Entrepreneurship and Public Policy. https://doi.org/10.1108/jepp-03-20190018

Dos Santos, A. P., \& Chaczko, Z. (2019). Blockchain: Status-quo, enablers and inhibitors. 26th International Conference on Systems Engineering, ICSEng 2018 - Proceedings, December 2018. https://doi.org/10.1109/ICSENG.2018.8638187

Fiedler, M., \& Sandner, P. (2017). Identifying leading blockchain startups on a worldwide level. In Frankfurt School Blockchain Center (FSBC) Working Paper. http://www.exploreip.com/2017_Analysis-of-leading-blockchain-startups-worldwide.pdf

Fisch, C. (2019). Initial coin offerings (ICOs) to finance new ventures. Journal of Business Venturing, 34(1), 1-22. https://doi.org/10.1016/j.jbusvent.2018.09.007 
García Sáez, M. I. (2020). Blockchain-enabled platforms: Challenges and recommendations. International Journal of Interactive Multimedia and Artificial Intelligence, 6(3), 73. https://doi.org/10.9781/ijimai.2020.08.005

Gartner, W. B. (1985). A conceptual framework for describing the phenomenon of new venture creation. Academy of Management Review, 10(4), 696-706. https://doi.org/https://doi.org/10.5465/amr.1985.4279094

Giarratana, M. S. (2004). The birth of a new industry: Entry by start-ups and the drivers of firm growth: The case of encryption software. Research Policy, 33(5), 787-806. https://doi.org/10.1016/j.respol.2004.01.001

Gogan, J. L., Goode, H. E., Gogan, J., \& Goode, H. E. (2020). An agile IT-enabled social startup. Conference of the Association-for-Information-Systems (AMCIS) 2020 Proceedings. 4. https://aisel.aisnet.org/amcis2020/social_inclusion/social_inclusion/4

Hart, C. (1998). Doing a literature review: Releasing the social science research imagination. Thousand Oaks: Sage.

Harzing, A. W., \& Alakangas, S. (2016). Google Scholar, Scopus and the Web of Science: a longitudinal and cross-disciplinary comparison. Scientometrics, 106(2), 787-804. https://doi.org/10.1007/s11192-015-1798-9

Jackson, E. (2017). Blockchain will turn the internet into the world's largest 'stock' market, says investor. CNBC. https://www.cnbc.com/2017/09/05/balaji-srinivasan-21-co-interviewon-blockchain.html

Jain, S., \& Simha, R. (2018). Blockchain for the common good: A digital currency for citizen philanthropy and social entrepreneurship. Proceedings - IEEE 2018 International Congress on Cybermatics: 2018 IEEE Conferences on Internet of Things, Green Computing and Communications, Cyber, Physical and Social Computing, Smart Data, Blockchain, Computer and Information Technology, IThings/Gree, 1387-1394. https://doi.org/10.1109/Cybermatics_2018.2018.00238

Jáki, E., Molnár, E. M., \& Kádár, B. (2019). Characteristics and challenges of the Hungarian startup ecosystem. Vezetéstudomány / Budapest Management Review, 50(5), 2-12. https://doi.org/10.14267/veztud.2019.05.01

Kher, R., Terjesen, S., \& Liu, C. (2020). Blockchain, Bitcoin, and ICOs: a review and research agenda. Small Business Economics. https://doi.org/10.1007/s11187-019-00286-y

Krafft, J., Lechevalier, S., Quatraro, F., \& Storz, C. (2014). Emergence and evolution of new industries: The path-dependent dynamics of knowledge creation. An introduction to the special section. Research Policy, 43(10), 1663-1665.

https://doi.org/10.1016/j.respol.2014.07.006

Li, K., Rollins, J., \& Yan, E. (2018). Web of Science use in published research and review papers 1997-2017: a selective, dynamic, cross-domain, content-based analysis.

Scientometrics, 115(1), 1-20. https://doi.org/10.1007/s11192-017-2622-5

Liu, S. (2020). Blockchain technology market size worldwide 2018-2025. Statista. https://www.statista.com/statistics /647231/worldwide-blockchain-technology-marketsize/ 
Massey, R., Dalan, D., \& Dakshinamoorthy, A. (2017). Initial coin offering: A new paradigm. Deloitte, 10. https://www2.deloitte.com/content/dam/Deloitte/us/Documents/processand-operations/us-cons-new-paradigm.pdf

Mickiewicz, T., \& Rebmann, A. (2020). Entrepreneurship as trust. Foundations and Trends@ in Entrepreneurship, 16(3), 244-309. https://doi.org/10.1561/0300000088

Morkunas, V. J., Paschen, J., \& Boon, E. (2019). How blockchain technologies impact your business model. Business Horizons, 62(3), 295-306. https://doi.org/10.1016/j.bushor.2019.01.009

Nambisan, S. (2017). Digital entrepreneurship: Toward a digital technology perspective of entrepreneurship. Entrepreneurship: Theory and Practice, 41(6), 1029-1055. https://doi.org/10.1111/etap.12254

Novak, M. (2019). Crypto-friendliness: understanding blockchain public policy. Journal of Entrepreneurship and Public Policy, 9(2), 165-184. https://doi.org/10.1108/JEPP-032019-0014

Nowiński, W., \& Kozma, M. (2017). How can blockchain technology disrupt the existing business models? Entrepreneurial Business and Economics Review, 5(3), 173-188. https://doi.org/10.15678/EBER.2017.050309

Park, G., Shin, S. R., \& Choy, M. (2020). Early mover (dis)advantages and knowledge spillover effects on blockchain startups' funding and innovation performance. Journal of Business Research, 109(C), 64-75. https://doi.org/10.1016/j.jbusres.2019.11.068

Park, J. Y., \& Sung, C. S. (2020). A business model analysis of blockchain technology-based startup. Entrepreneurship and Sustainability Issues, 7(4), 3048-3060. https://doi.org/10.9770/jesi.2020.7.4(32)

Schückes, M., \& Gutmann, T. (2020). Why do startups pursue initial coin offerings (ICOs)? The role of economic drivers and social identity on funding choice. Small Business Economics. https://doi.org/10.1007/s11187-020-00337-9

Shane, S. (2001). Technology regimes and new firm formation. Management Science, $47(9)$, 1173-1190. https://doi.org/10.1287/mnsc.47.9.1173.9785

Unalan, S., \& Ozcan, S. (2020). Democratising systems of innovations based on blockchain platform technologies. Journal of Enterprise Information Management, 33(6), 1511-1536. https://doi.org/10.1108/jeim-07-2018-0147

Weking, J., Mandalenakis, M., Hein, A., Hermes, S., Böhm, M., \& Krcmar, H. (2019). The impact of blockchain technology on business models - a taxonomy and archetypal patterns. Electronic Markets. https://doi.org/10.1007/s12525-019-00386-3

Zalan, T. (2018). Born global on blockchain. Review of International Business and Strategy, 28(1), 19-34. https://doi.org/10.1108/RIBS-08-2017-0069 